\title{
Penentuan Kadar Senyawa Aktif Cyanocobalamine Menggunakan Metode Spektrofotometri UV-VIS
}

\author{
Risma Sari ${ }^{1}$, Aisyah Salma Billa ${ }^{2}$ \\ ${ }^{1}$ Politeknik ATI Padang, Jl. Bungo Pasang Tabing Padang 25171, Indonesia
}

\section{ARTICLE INFORMATION}

Received: December 05, 2020

Revised: December 20, 2020

Available online: December 31, 2020

\section{KEYWORDS}

Cyanocobalamine, Pharmacopeia, UV-Vis Spectrophotometric

\section{CORRESPONDENCE}

Name: Risma Sari

E-mail: rismasari171@gmail.com

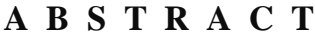

Cyanocobalmine is vitamin B12 which is widely used to treat or prevent deficiency (deficiency of vitamins) in various types of preparations. Cyanocobalmine in the 5th edition of Indonesian Pharmacopoeia literature can determine by UV-Vis Spectrophotometric method with water solvent. The purpose of this testing was to determine whether the levels of the active compound Cyanocobalamine from the 3 test parameters. In the description test where the sample tested is the same as the Cyanocobalamine specification, namely, crystal powder is dark red. Hot plate was used to determine drying shrinkage. Shrink drying was $2.25 \%-2.75 \%$ from the $\leq$ $12 \%$ requirement. The determination of the levels of the active compound of Cyanocobalamine fulfills the requirements, namely $96 \%-102.0 \%$. The results of the assay showed that the average level of Cyanocobalamine from 4 samples was $96.02 \%$, which met the standards set by the Pharmacopeia. Indonesia Edition V as a requirement for determining the levels of the active compound Cyanocobalamine.
\end{abstract}

\section{PENDAHULUAN}

Seiring dengan perkembangan teknologi serta ilmu pengetahuan dan adanya berbagai macam penyakit, membuat kebutuhan masyarakat akan produk obat yang berkualitas meningkat, sehingga menjadikan industri farmasi sebagai produsen obat bersaing untuk menghasilkan obat yang bermutu. Mutu obat sebagai parameter mencakup berbagai aspek, yaitu aman (safety), berkhasiat (efficacy) dan dapat diterima oleh konsumen (acceptable). Mutu obat harus dibentuk sejak awal mulai dari penanganan bahan awal, proses produksi (pengolahan dan pengemasan), penyimpanan hingga distribusi obat $[1,2]$.

Senyawa aktif harus melalui pengujian laboratorium untuk mengetahui standar mutu untuk pembuatan obat. Senyawa aktif yang digunakan adalah vitamin B12 (Cyanocobalamine) dimana harus memenuhi spesifikasi atau standar yang ditetapkan meliputi pemerian,uji susut pengeringan dan kadar Cyanocobalamine dengan metode spektrofotometri UV-Vis.

Vitamin B12 (Cyanocobalamine) berfungsi untuk membantu pertumbuhan sel darah merah dan mencegah penyakit anemia pernisiosa. Anemia pernisosa yaitu penyakit kekurangan zat besi dalam darah yang menyebabkan penyakit anemia. Anemia pernisiosa dapat disembuhkan saat mengonsumsi 100-200 gram hati sapi. Karena vitamin B12 ini hanya terdapat pada hewan khusus nya hati sehingga penyakit anemia ini bisa disembuhkan oleh obat vitamin B12 (Cyanocobalamine) $[2,3]$.

Sumber Vitamin B12 dari makanan adalah hati (ayam/sapi), daging, susu dan produk olahannya (telur, ikan, sayur, kedelai) dan produk olahan lainnya (tahu, tempe, tauco dan rumput laut), Vitamin B12 diproduksi juga oleh banyak mikroorganisme. Vitamin B12 memiliki stabilitas yang tinggi terhadap panas, sehingga vitamin B12 dalam bahan pangan yang dimasak dapat dipertahankan. Namun, vitamin B12 menunjukkan rangsangan yang tinggi terhadap cahaya, oksigen, serta lingkungan yang asam atau basa [4].

Vitamin B12 (Cyanocobalamine) memiliki pemerian hablur merah tua atau serbuk hablur merah, mudah larut dalam air dan dalam etanol, tidak larut dalam aseton, kloroform, dan eter. Vitamin B12 memiliki bentuk anhidrat dan sangat higroskopik. Jika terpapar udara 
menyerap air tidak lebih dari $12 \%$. Cyanocobalamine mengandung tidak kurang dari 96,0\% dan tidak lebih dari $102 \%$, dihitung terhadap zat yang telah dikeringkan. (FIV, 2014). Vitamin B12 dapat diidentifikasi dengan menggunakan metode spektrofotometri UV-Vis dan menggunakan pelarut air dengan panjang gelombang maksimum $361 \mathrm{~nm}$ (USP 38 - NF 33, 2015) [1,5,6].

Molekul vitamin B12 memiliki dua bagian yang khas yaitu bagian yang menyerupai nukleotida dimana 5,6 dimetil benzimidazol terikat pada D-ribosa melalui ikatan glikosida bagian ribosa mengandung gugus fosfat pada posisi 3, dan bagian pusat suatu sistem cincin "corrin" yang menyerupai forfirin tetapi mengandung atom cobalt. Keempat atom nitrogen dibagian dalam cincin "corrin" terikat pada sebuah atomCo dan karena itulah vitamin B12 sering disebut sebagai kobalamin. Pada bentuk yang biasa diisolasi, misalnya dari hati, keenam koordinatnya tersebut mengikat 5deaksiadenosin melalui gugus metilnya [7].

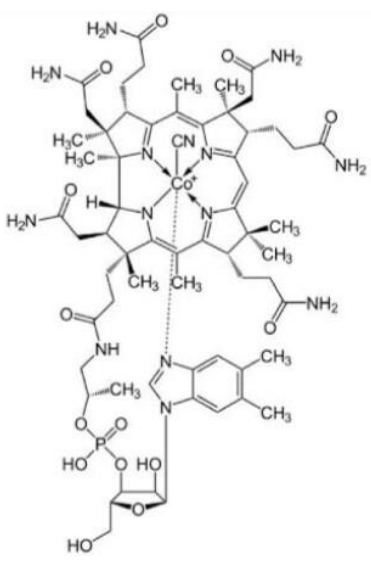

Gambar 1. Rumus Bangun Vitamin B12

$\begin{array}{ll}\text { Nama Kimia } & : \text { c - }-(5,6-d i m e t h y l b e n z i m i d a z o l y l) \\ & \text { cobamidcyanide } \\ \text { Rumus Molekul } & : \text { C63H88CoN14P } \\ \text { Berat Molekul } & : 1355,37 \\ \text { Pemerian } & : \text { Serbuk kristal merah tua } \\ \text { Kelarutan } & : \text { Mudah larut dalam air dan dalam } \\ & \text { etanol, tidak larut dalam Aseton, } \\ & \text { kloroform, dan eter. }\end{array}$

Berdasarkan sifat Vitamin B12 yang tidak stabil dengan udara dan cahaya maka penentuan kadar Cyanocobalamine dilakukan dengan menggunakan panjang gelombang maksimum $361 \mathrm{~nm}$. Menurut european pharmacopoeia panjang gelombang untuk Cyanocobalamine mempunyai dua panjang gelombang maksimum yaitu pada $361 \mathrm{~nm}$ dan $550 \mathrm{~nm}$.

Panjang gelombang $361 \mathrm{~nm}$ merupakan panjang gelombang mutlak untuk menentukan kadar senyawa aktif Cyanocobalamine sedangkan panjang gelombang maksimum untuk sampel obat bisa menggunakan panjang gelombang $361 \mathrm{~nm}$ dan $550 \mathrm{~nm}$ tergantung dari sifat obat yang dianalisis $[1,6]$.

\section{METODOLOGI}

Penelitian ini dilakukan di laboratorium kimia dengan menggunakan , aquades, aseton, etanol (96\%). Sampel yang digunakan Cyanocobalamine Alat yang digunakan pada penelitian ini adalah seperangkat alat Spektrofotometri UV-Vis, labu ukur $200 \mathrm{~mL}$ dan 500 $\mathrm{mL}$, erlenmeyer $100 \mathrm{~mL}$, cawan penguap, timbangan analitik, bulp, pipet tetes, hot plate, spatula, pipet gondok $1 \mathrm{ml}$, gelas ukur $100 \mathrm{ml}$, tabung kecil $10 \mathrm{ml}$.

\section{Pemerian}

Sebanyak $1 \mathrm{mg}$ sampel dilarutkan masing-masing dengan air, aseton dan etanol (96\%), lalu diamati warna, wujud dan kelarutan.

\section{Susut Pengeringan}

ditimbang cawan penguap kosong (A gram). Ditimbang $40 \mathrm{mg}$ sampel kedalam cawan penguap, dikeringkan pada suhu $105^{\circ} \mathrm{C}$ selama 2 jam dengan menggunakan Hot Plate. Dinginkan dalam desikator lalu timbang (B gram). Syarat susut pengeringan dari Cyanocobalamine adalah $\leq 12 \%$.

\section{Penetapan Kadar}

Sebanyak $100 \mathrm{mg}$ Cyanocobalamine dilarutkan dalam labu ukur $500 \mathrm{ml}$ dengan Aquades (larutan 1). Lalu Dipipet $25 \mathrm{ml}$ larutan 1 dan dilarutkan dalam labu ukur $200 \mathrm{ml}$ dengan Aquades. Diukur absorban dengan Spektrofotometer UV-Vis pada panjang gelombang maksimum $361 \mathrm{~nm}$ dengan menggunakan blanko aquades. Diukur sebanyak 4 sampel.

\section{HASIL DAN PEMBAHASAN}

\section{Uji Pemerian}

Hasil yang diperoleh dari Uji Pemerian yaitu Kristal berwarna merah kegelapan, mudah larut dalam air dan etanol (96\%), tidak larut dalam aseton, kloroform dan eter. Bahan tidak berair dan sangat higroskopik. Berdasarkan parameter uji pemerian, sampel yang diuji sama dengan spesifikasi Cyanocobalamine yaitu, serbuk hablur berwarna merah kegelapan dan dapat larut dalam air. Pengujian pemerian ini dilakukan secara visual. Pengujian pemerian dilakukan untuk melihat fisik dari Cyanocobalamine, agar disaat pembuatan obat jadi tersebut memenuhi kriteria syarat secara fisik. Karena jika secara fisik Cyanocobalamine tidak memenuhi syarat, maka obat yang akan dihasilkan tidak memenuhi standar dari obat jadi, dikarenakan fisik dari Cyanocobalamine yang tidak sesuai. 


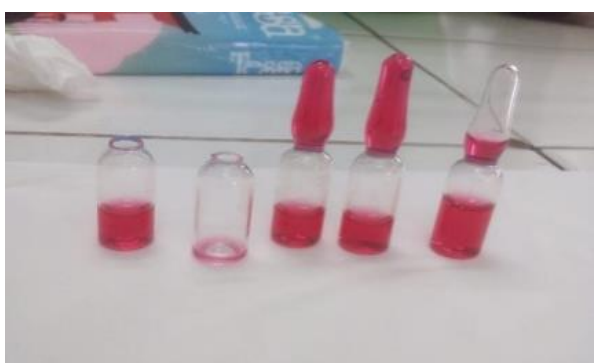

Gambar 2. Hasil Sampel dengan Pelarut air

\section{Uji Susut Pengeringan}

Hasil yang didapatkan saat uji Susut Pengeringan yaitu $\leq 12 \%$ sesuai dengan standar yang telah ditetapkan oleh Farmakope Indonesia Edisi V. Susut pengeringan adalah untuk melihat adanya zat mudah menguap ataupun adanya kadar air yang ada pada sampel tersebut. Sedangkan parameter uji dari kadar Cyanocobalamine dilakukan untuk memastikan kadar yang terkandung ke dalam sampel Cyanocobalamine tersebut.

Uji susut pengeringan dilakukan untuk melihat adanya zat mudah menguap ataupun adanya kadar air yang ada pada sampel tersebut yang nantinya akan menentukan kadar kering dari Cyanocobalamine. Uji susut pengeringan ditentukan untuk menghilangkan kadar air yang terdapat dalam sampel tersebut. Pada tabel 4.1 kadar air dalam sampel Cyanocobalamine didapatkan sebesar 2,25\% - 2,75\%. Syarat dari susut pengeringan adalah $\leq 12 \%$, Hasil telah memenuhi standar yang ditetapkan Pharmacopeia.

Tabel 1. Hasil Pengujian Kadar Susut Pengeringan

\begin{tabular}{ccccrr}
\hline No. & $\begin{array}{l}\text { Berat cawan kosong + sampel } \\
\text { sebelum susut pengeringan }\end{array}$ & $\begin{array}{l}\text { Berat cawan kosong + sampel } \\
\text { sebelum susut pengeringan }\end{array}$ & $\begin{array}{l}\text { Berat sampel } \\
\text { tertimbang (gram) }\end{array}$ & $\begin{array}{l}\text { Hasil susut } \\
\text { pengeringan (LOD) }\end{array}$ & $\begin{array}{c}\text { Hasil } \\
(\%)\end{array}$ \\
\hline 1 & 27,2091 & 27,2082 & 0,0400 & 0,0225 & 2,25 \\
2 & 26,2792 & 26,2783 & 0,0400 & 0,0225 & 2,25 \\
3 & 26,6120 & 26,6109 & 0,0402 & 0,0273 & 2,73 \\
4 & 26,3103 & 26,3092 & 0,0400 & 0,0275 & 2,75 \\
\hline & & Standar menurut Pharmacopeia & & $\leq 12$
\end{tabular}

\section{Penentuan Kadar Cyanocobalamine}

Penentuan kadar dilakukan dengan menggunakan alat Spektrofotometer UV-Vis pada panjang gelombang maksimum $361 \mathrm{~nm}$.

Tabel 2 Hasil Penetapan Kadar Cyanocobalamine

\begin{tabular}{cccc}
\hline No. & Berat (mg) & Absorban & Hasil (\%) \\
\hline 1. & 100,10 & 0,49700 & 95,96 \\
2. & 100,01 & 0,49589 & 95,83 \\
3 & 100,06 & 0,49866 & 96,32 \\
4 & 100,07 & 0,49686 & 95,97 \\
\hline \multicolumn{3}{c}{ Rata-rata } & 96,02 \\
\hline \multicolumn{4}{c}{ Standar Menurut } \\
Pharmacopeia
\end{tabular}

Penentuan kadar Cyanocobalamine dilakukan dengan metode Spektrofotometri UV-Vis dengan menggunakan panjang gelombang maksimum pada literatur adalah $361 \mathrm{~nm}$ dan menggunakan pelarut air yang mudah larut dalam Cyanocobalamine, hasil yang didapatkan yaitu 96,02\%. Jika dosis atau kadar dari Cyanocobalamine kurang, maka obat tersebut tidak berfungsi sebagaimana mestinya dan jika kadar Cyanocobalamine melebihi dosis maka akan diekskresikan melalui urin. Oleh karena itu harus dilakukan pengujian senyawa aktif Cyanocobalamine secara akurat sesuai dengan standar.

Kadar Cyanocobalamine yang didapatkan memenuhi syarat yang ditentukan yaitu 96,0-102,0\%. Tingginya syarat kadar Cyanocobalamine dikarenakan kadar ini akan mengalami penurunan pada produksi nantinya.

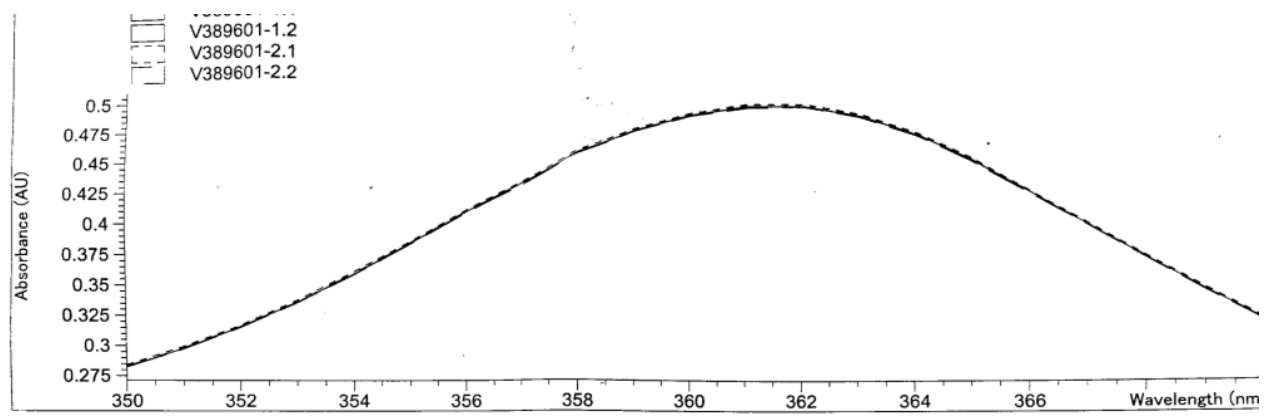

Gambar 3. Hasil Absorbansi Penentuan kadar Cyanocobalamine dengan Spektrofotometer

34 Sari et al. 


\section{KESIMPULAN}

Berdasarkan penelitian yang telah dilakukan di dapatkan kesimpulan bahwa senyawa aktif Cyanocobalamine pada uji susut pengeringan didapatkan sebesar 2,25\% 2,75 \%. Dan kadar Cyanocobalamine sebesar 96,02\%. Sesuai dengan Farmakope Indonesia Edisi V.

\section{DAFTAR PUSTAKA}

[1] Anonim, United States Pharmacopeia 38 th edition., Rockville, MD United States Pharmacopeia Convention, 2015 pp 2965-2966.

[2] Lukman Hakim, Farmakoniketik: Pengembangan Obat-Kalkulasi Regigimen Dosis-Pengendalian Mutu Obat, 2018, Bursa Ilmu, Yogyakarta.

[3] Amalia Hanif, Pemastian Mutu Obat, 2006, Penerbit Buku Kedokteran EGC, Jakarta.

[4] Gille,,D.,Schmid,A. Vitamin B12 in Meet And Dairy Product Nutr Rev 73, 2015, pp 106-115.

[5] Departemen Kesehatan Republik Indonesia. Farmakope Indonesia Edisi V Buku II Jakarta Departemen Kesehatan Republik Indonesia, 2014.

[6] Hardjono, S. Dasar-Dasar Spektroskopi. 2019. UGM Press. Yogyakarta.

[7] Kim,J., Gherasm,C, et al,. Decyanation of Vitamin B12 by A Trafficking Chaperone. Proc.Natl Acad. Sci. USA 105, 2008, pp 14551-14554. 